\title{
FAKTOR-FAKTOR YANG BERHUBUNGAN DENGAN KEJADIAN LEUKORRHEA (KEPUTIHAN) PADA REMAJA PUTRI KELAS X
}

\author{
ASSOCIATED FACTORS OF LEUCORRHOEA FOR FEMALE \\ STUDENT IN FIRST GRADE \\ Rinda Lamdayani \\ Sekolah Tinggi Ilmu Kesehatan Abdurahman Palembang, Jl. Sukajaya No.7 Kol. H.Burlian KM. 5,5 \\ Palembang, Sumatera Selatan, Indonesia \\ email: rindalamdayani5@gmail.com
}

\begin{abstract}
ABSTRAK
Masalah kesehatan reproduksi khususnya yang sering dikeluhkan adalah keputihan, tak jarang keputihan dapat menggangu hingga menyebabkan ketidak nyamanan dalam aktivitas sehari-hari. Tujuan penelitian ini untuk mengetahui faktor-faktor yang berhubungan dengan kejadian Leukorrhea (keputihan) pada remaja putri kelas $x$ SMA Karya Ibu Palembang. Metode penelitian ini adalah Survey Analitik dengan rancangan Cross Sectional. Populasi adalah seluruh siswi SMA Karya Ibu Palembang dengan Sampel seluruh Total Sampling yang berjumlah 60 responden. Analisa data menggunakan uji Chi-Square. Penelitian ini dilakukan pada bulan Mei 2017. Berdasarkan analisa bivariat dengan menggunakan uji Chi-Square didapakan variabel pengetahuan $\rho$ Value $=0,033<0,05$, usia remaja $\rho$ Value $=0,023<0,05$, dan sikap $\rho$ Value $=0,046<0,05$. Hal ini menunjuksn hubungan yang bermakna antara pengetahuan, Usia Remaja, dan Sikap dengan kejadian Leukorrhea (Keputihan).
\end{abstract}

Kata Kunci : Pengetahuan, Usia Remaja, Dan Sikap, Leukorrhea (Keputihan)

\begin{abstract}
Reproductive health problems, especially the often complained of whitish, not infrequently whitish can interfere to cause discomfort in daily activities. The purpose of this study to determine the factors associated with the incidence of Leukorrhea (leucorrhoea) in teenage girls $x$ high school SMA Ibu Palembang. This research method is Analytical Survey with Cross Sectional design. The population is all students of SMA KaryaIbu Palembang with 60 respondents. Samples used in Total Sampling. Data analysis using Chi-Square test. This research was conducted in May 2017. Based on bivariate analysis using Chi-Square test, it is applied by knowledge variable $\rho$ Value $=0,033<0,05$, adolescent age $\rho$ Value $=0,023<0,05$. And attitude $\rho$ Value $=$ $0,046<0,05$. There is a significant relationship with knowledge, age of adolescence, and attitude with the incidence of Leukorrhea (Dish).
\end{abstract}

Keywords

: Knowledge, Young Age, And Attitude, Leukorrhea (Dish) 


\section{PENDAHULUAN}

Salah satu masalah kesehatan reproduksi khususnya yang sering dikeluhkan adalah keputihan. Tak jarang keputihan dapat menggangu hingga menyebabkan ketidaknyamanan dalam aktivitas seharihari. Keputihan dapat berupa fisiologi (normal) dan patologis (tidak normal). Dalam keadaan normal, vagina akan menghasilkan cairan yang tidak berwarna bening, tidak berbau, tanpa rasa panas atau nyeri. Sedangkan keputihan tidak normal akan sebaliknya, biasanya berwarna kuning, hijua atau ke abu-abuan, berbau amis atau busuk, jumlahnya banyak dan disertai gatal dan rasa atau nyeri pada daerah vagina ${ }^{1}$.

Kesehatan reproduksi adalah suatu keadaan fisik, mental, dan sosial yang utuh, bukan hanya bebas dari penyakit atau kecacatan dalam segala aspek yang berhubungan dengan sistem reproduksi, fungsi serta prosesnya $^{2}$.

Bahwa sekitar (75\%) perempuan di dunia akan mengalami keputihan paling tidak sekali seumur hidup nya, dan sebanyak (45\%) akan mengalami dua kali atau lebih, sedangkan wanita Eropa yang mengalami keputihan sebanyak $(25 \%)^{3}$.

Data International menyatakan, jumlah wanita di dunia pada tahun 2013 sebanyak 6,7 miliiar jiwa, (75\%) wanita tersebut pernah mengalami keputihan. Pada wanita Eropa pada tahun 2013 yang mengalami keputihan sebanyak (25\%) dari 739.004.470 jiwa, sedangkan wanita Indonesia (75\%) mengalami keputihan dari 237.641.326 jiwa pada tahun $2013^{4}$.

Berdasarkan penelitian akibat dari keputihan tidak normal bila lambat ditangani dapat berakibat vaginosis bakterialis $(64,71 \%)$, candidiasis vulvo vaginitis $(32,35 \%)$, dan campuran antara candidiasis dengan vaginosis bakterialis
$(2,94 \%)$. Tidak hanya itu, keputihan merupakan gejala awal dari kanker leher rahim (kanker serviks/carsinoma serviks). Kasus kanker leher rahim 90\% ditandai dengan keputihan, yang lama kelamaan akan berbau busuk karena adanya proses infeksi dan nekrosis (kematian) jaringan akibat kanker tersebut ${ }^{5}$.

Hasil survey kesehatan reproduksi remaja Indonesia (SKRRI) 2007, menyatakan pengetahuan remaja umur 15-24 tahun tentang kesehatan reproduksi masih rendah (21\%) remaja perempuan tidak mengetahui sama sekali perubahan yang terjadi pada remaja. Berdasarkan hasil penilitian yang dilakukan oleh Deissy (2013) di SMA Negeri 2 Penilang di dapatkan 60 responden, dari 27 responden $(45,5 \%)$ berpengetahuan baik tentang keputihan, dan 33 responden (55\%) memiliki pengetahuan kurang. Data peneltian pada remaja putri SMA Muhammadiyah 1 Semarang didapatkan dari 73 remaja putri yang pernah mengalami keputihan, yang melakukan pencegahan keputihan dengan baik sebanyak 29 responden $(39,7 \%), 31$ responden $(42,5 \%)$ melakukan dengan cukup, dan 13 responden $(17,8 \%)$ kurang melakukan pencegahan keputihan

Berdasarkan Obgin RSCM, yang terinfeksi daerah kemaluan didapatkan data dari 223 remaja (2\%) dari usia 11-15 tahun, dan (12 $\%)$ dari usia 16-20 tahun dari 223 remaja tersebut terinfeksi di daerah kemaluan ${ }^{6}$.

Berdasarkan penelitian Deissy (2013), di SMA Negeri 2 Pinelang didapatkan remaja yang menderita keputihan antara umur 1415 tahun sebanyak 15 responden (25\%), sedangkan pada umur16-17 tahun sebanyak 45 responden $(75 \%)^{7}$.

Remaja wanita cenderung memiliki masalah kesehatan reproduksi yang lebih berat di bandingkan laki-laki. Dampak keputihan yang timbul akibat keputihan pada remaja yaitu rasa yang tidak percaya 
CENDEKIA MEDIKA

ISSN: 2503-1392

e-ISSN: 2620-5424

diri dalam menjalankan aktivitas sehari-hari dikarenakan rasa gatal, berbau busuk bahkan rasa seperti terbakar pada vulva. Menurut SKRRI Tahun 2007 media memegang peran penting dalam penyebarluaskan informasi tentang Kesehatan Reproduksi. Remaja mendapatkan informasi tentang kesehatan reproduksi melalui televisi $38,2 \%$, radio $24,4 \%$ dan koran $20,8 \%^{8}$.

Pada saat penulis melakukan wawancara dengan kepala sekolah, bagian Tata Usaha, guru di sekolah menyatakan bahwa, belum pernah diberikan pelajaran tentang kesehatan reproduksi belumnya karena tidak ada pada kurikulum pendidikan.Salah satusiswa kelas $\mathrm{X}$ yang diwawancarai penulis mengatakan sering mengalami keputihan ketika akan haid tapi tidak tau apakah normal atau tidak dan biasanya siswa tersebut hanya membiarkan saja hingga hilang sendiri. Selain itu, di sekolah ini juga tidak pernah dilakukan penyuluhan dan penelitian tentang keputihan sebelumnya.

Tujuan penelitian ini untuk mengetahui faktor-faktor yang berhubungan dengan kejadian keputihan pada remaja putri kelas X SMA Karya Ibu Palembang Tahun 2017.

\section{METODE}

Jenis penelitian ini merupakan jenis penelitian Survei Analitik dengan rancangan Cross Sectional, Dengan jumlah populasi sebanyak 60 responden dan teknik pengambilan sampel menggunakan Total Sampling dan mendapatkan sampel 60 responden.

\section{HASIL}

Tabel 1 Distribusi Frekuensi Kejadian Leukorrhea (Keputihan) padaRemaja Putri di SMA Karya Ibu Palembang

\begin{tabular}{llcc}
\hline No. & Keputihan & Frekuensi $($ F) & Presentase (\%) \\
\hline 1. & Ya & 15 & 25 \\
2. & Tidak & 45 & 75 \\
\hline & Jumlah & 60 & 100 \\
\hline
\end{tabular}

Berdasarkan Tabel 1 menunjukkan bahwa dari 60 responden yang mengalami keputihan sebesar 15 responden (25\%) sedangkan yang tidak keputihan sebesar 45 responden $(75 \%)$.

Tabel 2 Distribusi Frekuensi Pengetahuan dengan Kejadian Leukorrhea (Keputihan)padaRemaja Putri di SMA Karya Ibu Palembang

\begin{tabular}{llcc}
\hline No. & Pengetahuan & Frekuensi $($ F) & Presentase (\%) \\
\hline 1. & Baik & 36 & 60 \\
2. & Kurang & $\mathbf{2 4}$ & $\mathbf{4 0}$ \\
\hline & Jumlah & 60 & 100 \\
\hline
\end{tabular}

Berdasarkan Tabel 2 menunjukan bahwa dari 60 responden yang memiliki pengetahuan baik tentang keputihan yaitu 36 responden $(60 \%)$, sedangkan responden 
CENDEKIA MEDIKA

ISSN: 2503-1392

e-ISSN: 2620-5424

yang pengetahuannya kurang berjumlah 24

Tabel 3 Distribusi Frekuensi Usia dengan Kejadian Leukorrhea (Keputihan)padaRemaja Putri di SMA Karya Ibu Palembang

\begin{tabular}{llcc}
\hline No. & Usia Remaja & Frekuensi $($ F) & Presentase (\%) \\
\hline 1. & Remaja Awal & 35 & 58,3 \\
2. & Remaja Akhir & 25 & 41,7 \\
\hline & Jumlah & 60 & 100 \\
\hline
\end{tabular}

Berdasarkan Tabel 3 menunjukan bahwa dari 60 responden yang berusia antara 1116 tahun yaitu sebesar 35 responden
$(58,3 \%)$ lebih besar dari responden yang berumur 17-20 tahum yaitu sebesar 25 responden
$(41,7 \%)$

Tabel 4 Distribusi Frekuensi Sikap dengan Kejadian Leukorrhea (Keputihan) padaRemaja Putri di SMA Karya Ibu Palembang

\begin{tabular}{llcc}
\hline No. & Sikap & Frekuensi $($ F $)$ & Presentase (\%) \\
\hline 1. & Positif & 37 & 61,7 \\
2. & Negatif & 23 & $\mathbf{3 8 , 3}$ \\
\hline & Jumlah & 60 & 100 \\
\hline
\end{tabular}

Berdasarkan Tabel 4 Menunjukkan bahwa dari 60 responden yang mempunyai sikap positif sebesar 37 responden $(61,7 \%)$ sedangkan yang mempunyai sikap negatif sebesar $23(38,3 \%)$.

Tabel 5 Hubungan Pengetahuan dengan Kejadian Leukorrhea (Keputihan) padaRemaja Putri di SMA Karya Ibu Palembang

\begin{tabular}{|c|c|c|c|c|c|c|c|c|}
\hline \multirow{3}{*}{ No } & \multirow{3}{*}{ Pengetahuan } & \multicolumn{4}{|c|}{ Keputihan } & \multirow{2}{*}{\multicolumn{2}{|c|}{ Jumlah }} & \multirow[t]{3}{*}{ p Value } \\
\hline & & \multicolumn{2}{|c|}{$\mathbf{Y a}$} & \multicolumn{2}{|c|}{ Tidak } & & & \\
\hline & & $\mathbf{n}$ & $\%$ & $\mathbf{n}$ & $\%$ & $\mathbf{N}$ & $\%$ & \\
\hline$\overline{1}$ & Baik & 13 & 36,1 & 23 & 63,9 & 36 & 60 & נ, \\
\hline 2 & Kurang & 2 & 8,3 & 22 & 91,7 & 24 & 40 & \\
\hline & Jumlah & 15 & 25 & 45 & 75 & 60 & 100 & \\
\hline
\end{tabular}

Berdasarkan Tabel 5 menunjukkan bahwa dari 36 responden yang mengalami keputihan berpengetahuan baik yaitu sebesar 13 responden $(36,1 \%)$ lebih kecil dari yang tidak keputihan yaitu sebesar 23 responden $(63,9 \%)$ sedangkan dari 24 responden yang mengalami keputihan berpengerahuan kurang yaitu sebesar 2 responden $(8,3 \%)$, lebih kecil dari yang tidak keputihan yaitu sebesar 22 responden $(91,7 \%)$. 
ISSN: 2503-1392

e-ISSN: 2620-5424

Tabel 6 Hubungan Usia dengan Kejadian Leukorrhea (Keputihan) padaRemaja Putri di SMA Karya Ibu Palembang

\begin{tabular}{|c|c|c|c|c|c|c|c|c|}
\hline \multirow{3}{*}{ No } & \multirow{3}{*}{ Usia Remaja } & \multicolumn{4}{|c|}{ Keputihan } & \multirow{2}{*}{\multicolumn{2}{|c|}{ Jumlah }} & p Value \\
\hline & & \multicolumn{2}{|c|}{$\mathbf{Y a}$} & \multicolumn{2}{|c|}{ Tidak } & & & \multirow{5}{*}{0,023} \\
\hline & & $\mathbf{n}$ & $\%$ & $\mathbf{n}$ & $\%$ & $\mathbf{N}$ & $\%$ & \\
\hline 1 & Remaja Awal & 13 & 37,1 & 22 & 62,9 & 35 & 58,3 & \\
\hline 2 & Remaja Akhir & 2 & 8 & 23 & 92 & 25 & 41,7 & \\
\hline \multicolumn{2}{|c|}{ Jumlah } & 15 & 25 & 45 & 75 & 60 & 100 & \\
\hline
\end{tabular}

Berdasarkan Tabel 6 menunjukkan bahwa dari 35 responden dengan remaja awal yang mengalami keputihan yaitu sebanyak 13 responden $(37,1 \%)$, lebih besar dari yang tidak mengalami keputihan yaitu sebesar 22 responden $(62,9 \%)$. Sedangkan dari 35 responden dengan remaja akhir yang mengalami keputihan sebanyak 2 responden $(8 \%)$, sedangkan yang tidak mengalami keputihan yaitu sebanyak 23 responden $(92 \%)$.

Tabel 7 Hubungan Sikap dengan Kejadian Leukorrhea (Keputihan) padaRemaja Putri di SMA Karya Ibu Palembang

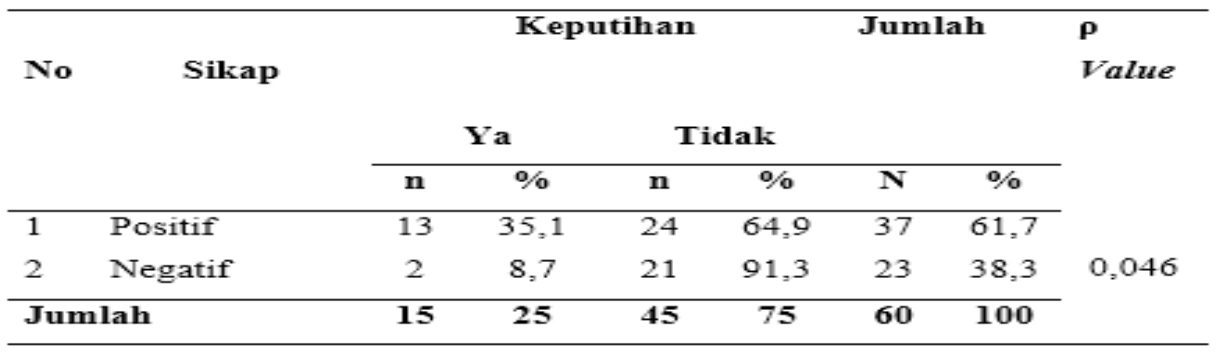

Berdasarkan Tabel 7 menunjukkan bahwa dari 37 responden yang mempunyai sikap positif mengalami keputihan yaitu sebanyak 13 responden $(35,1 \%)$, sedangkan sikap positif yang tidak mengalami keputihan yaitu sebesar 24 responden (64,9\%). Sedangkan, dari 23 responden yang mempunyai sikap negatif yang mengalami keputihan sebanyak 2 responden $(8,7 \%)$, sedangkan yang mempunyai sikap negatif yang tidak mengalami keputihan yaitu sebanyak 21 responden $(91,3 \%)$.

\section{PEMBAHASAN}

Berdasarkan Tabel 5 menunjukkan bahwa dari 36 responden yang mengalami keputihan berpengetahuan baik yaitu sebesar 13 responden $(36,1 \%)$ lebih kecil dari yang tidak keputihan yaitu sebesar 23 responden $(63,9 \%)$ sedangkan dari 24 responden yang mengalami keputihan berpengerahuan kurang yaitu sebesar 2 responden $(8,3 \%)$, lebih kecil dari yang tidak keputihan yaitu sebesar 22 responden $(91,7 \%)$. Didapatkan $\rho$ value dihitung $0,033<\alpha 0,05$.

Pengetahuan adalah hasil dari tahu dan ini terjadi setelah orang melakukan pengindraan terhadap suatu obyek tertentu. Pengindraan terjadi melalui panca indra manusia, yakni indra penglihatan, pendengaran, penciuman, rasa dan raba. Sebagian besar pengetahuan manusia diperoleh melalui mata dan telinga? . 
Pengetahuan merupakan salah satu faktor predisposing terbentuknya perilaku pada remaja, yaitu faktor yang memotivasi. Foktor ini berasal dari dalam diri seorang remaja yang menjadi alasan atau motivasi untuk melakukan suatu prilaku. Pentingnya remaja mengetahui tentang keputihan agar wanita khususnya remaja mengetahui tentang keputihan, tanda dan gejala keputihan penyebab, dan dapat membedakan antara keputihan fisiologis dan patologis sehingga wanita dapat mencegah, menangani dan segera melakukan pemeriksaan apabila terdapat tanda dan gejala keputihan yang tidak normal.

Hasil penelitian ini sejalan dengan penelitian Deissy (2013), dengan judul Hubungan antara Pengetahuan dan Perilaku Remaja Putri dalam Menjaga Kebersihan Alat Genitalia dengan kejadian Keputihan di SMA Negeri 2 Pineleng. Jenis penelitian ini menggunakan observasional analitik dengan rancanga cross sectional yang menggunakan Chi-square test dengan taraf signifikan $(a=0,05)$. Populasi dalam penelitian ini seluruh siswa SMA Negeri 2 Pineleng berjumlah 60 responden. Pengambilan data menggunakan kuisioner. Hasil penelitian menujukan bahwa pengetahuan kurang sebesar 33 responden dengan persenttase $55 \%$ dan pengetahuan baik sebesar 27 responden dengan persentase $45 \%{ }^{10}$.

Berdasarkan Tabel 6 menunjukkan bahwa dari 35 responden dengan remaja awal yang mengalami keputihan yaitu sebanyak 13 responden $(37,1 \%)$, lebih besar dari yang tidak mengalami keputihan yaitu sebesar 22 responden $(62,9 \%)$. Sedangkan dari 35 responden dengan remaja akhir yang mengalami keputihan sebanyak 2 responden $(8 \%)$, sedangkan yang tidak mengalami keputihan yaitu sebanyak 23 responden (92\%).Didapatkan $\rho$ value dihitung $0,023<\alpha=0,05$.
Umur atau usia adalah satuan waktu yang mengukur waktu keberadaan suatu benda atau makhluk, baik yang hidup maupun yang mati. Semisal, umur manusia dikatakan lima belas tahun diukur sejak dia lahir hingga waktu itu dihitung. Oleh demikian, umur itu diukur dari lahir hingga semasa (masa kini) ${ }^{11}$.

Kejadian keputihan dipengaruhi oleh usia, yang disebabkan perubahan siklus hormonal, sesuai dengan teori yang menyatakan bahwa keputihan fisiologis lebih banyak dipengaruhi oleh faktor hormonal yang normal. Dalam siklus kehidupan wanita, produksi hormon estrogen mulai nyata pada saat akil baliq sampai menoupose.Pada periode kehidupan reproduksi, hormon tersebut yang bersirkulasi dalam darah sehingga mencapai jumlah yang cukup dan berpengaruh terhadap perkembangan dan fungsi beberapa organ tubuh. Pada sekret vagina normal akan dirasakan bertambah dengan atau tanpa keluhan pada keadaan estrogen yang tinggi dalam keadaan tubuh (Hyperestrogenisme) $^{12}$.

Penelitian ini sejalan dengan penelitian Donatila (2011), Hubungan antara Pengetahuan Dan Perilaku Menjaga Kebersihan Genitalia Eksterma Dengan Kejadian Keputihan Pada Siswa SMA N 4 Semarang, Penelitian ini menggunakan rancangan penelitian observasional dengan pendekatan cross sectional. Subjek penelitian ini adalah 64 siswa kelas $\mathrm{X}$ dan XI SMA Negeri 4 Semarang periode 20102011, Pengambilan data dilakukan dengan pengisian kuesioner terpimpin yang telah diuji cobakan. Analisa data dilakukan dengan menggunakan uji hipotesis fisher exact tes/Chi Square. Kelas XI sebesar 38 responden $(59,4 \%)$ adalah lebih banyak dibandingkan kelas X (40,6\%). Sedangkan distribusi usia responden, jumlah terbesar yaitu usia 16 tahun sebanyak 33 respnden $(51,6 \%)$ dan usia responden termudah 
adalah usia 14 tahun sebanyak tiga responden $(4,7 \%)^{13}$.

Berdasarkan Tabel 7 menunjukkan bahwa dari 37 responden yang mempunyai sikap positif mengalami keputihan yaitu sebanyak 13 responden $(35,1 \%)$, sedangkan sikap positif yang tidak mengalami keputihan yaitu sebesar 24 responden $(64,9 \%)$. Sedangkan, dari 23 responden yang mempunyai sikap negatif yang mengalami keputihan sebanyak 2 responden $(8,7 \%)$, sedangkan yang mempunyai sikap negatif yang tidak mengalami keputihan yaitu sebanyak 21 responden (91,3\%).Didapatkan $\rho$ value dihitung $0,046<\alpha=0,05$.

Sikap remaja mengenai penanganan keputihan tergantung dari respon yang baik, yang merupakan kesepian untuk bereaksi terhadap suatu objek serta hal-hal yang dapat membentuk sikap seperti pengalaman pribadi, pengaruh orang lain yang dianggap penting, pengaruh kebudayaan, media massa, lembaga pendidikan dan lembaga agama, faktor emosional dan pengetahuan yang ia miliki, maka semakin bagus pula cara remaja menyikapi diri penanganan keputihan.

Penelitian ini sejalan dengan penelitian yang dilakukan oleh Asyrina (2013) dengan judul hubungan tingkat pengetahuan dan sikap remaja putri tentang personal hygiene dengan kejadian keputihan pada remaja putri kelas XI di SMAN 5 kota Bukit tinggi, dimana hasil penelitian didapatkan bahwa tidak ada hubungan antara sikap pada remaja putri tentang personal hygiene kewanitaan dengan kejadian keputihan ${ }^{14}$.

\section{KESIMPULAN}

Ada hubungan yang bermakna antara pengetahuan dengan kejadian keputihan dengan $\rho$ value $0,033<\alpha 0,05$.

Ada hubungan yang bermakna antara usia remaja putri dengan kejadian keputihan di
SMA Karya Ibu Palembang Tahun 2017 dengan $\rho$ value $0,023<\alpha 0,05$.

Ada hubungan yang bermakna antara sikap dengan kejadian keputihan di SMA Karya Ibu Palembang Tahun 2017 dengan $\rho$ value $0,046<\alpha 0,05$.

\section{DAFTAR PUSTAKA}

1. Agustini. 2007. Keputihan: Si Putih Yang Menggangu. http://astaqauliyah.com

2. Nugroho. 2010. Buku ajar obstetri untuk mahasiswi kebidanan. Yogyakarta: Nuha media

3. Febilliawati. 2009. Kenali ciri keputuhan vagina apnormal (http://Kkesehatan .kompas.abnormal)

4. WHO (World Health Organization). 2010

5. Elistiyawaty. 2006. $75 \%$ Wanita RI Alami Keputihan. (www.detiknews.comDiakses 23 April 2014)

6. Deissy, Marceline. 2013.Antara Pengetahuan dan Prilaku Remaja Putri dalam Menjaga Pineleng. Volume 1, Nomor 1.Universitas Sam Ratulangi Manado, 1-5

7. Sarwono. 2011. Psikologi remaja. Edisi revisi. Jakarta: rajawali pers

8. Kusmiran. 2011. Kesehatan Reproduksi Remaja dan Wanita. Jakarta: SalembaMedika.

9. Notoadmojo, S. 2007. Metode Penelitian Kesehatan. Jakarta: Rineka Cipta.

10. Depkes, RI. 2009. Sistem kesehatan nasional. Jakarta

11. Ricky, Apriandi, M. 2005. Pengetahuan dan persepsi Siswi SMU Negeri 17 Plus PalembangTentang Leukorrhea. Skripsi. Palembang : Universitas Sriwijaya

12. Kuncoro. 2013. Kesehatan reproduksi remaja dan wanita. Jakarta selatan: Salimba medika 
CENDEKIA MEDIKA

ISSN: 2503-1392

e-ISSN: 2620-5424

13. Donatalia. 2011. Hubungan Antara Pengetahuan Dan Perilaku Menjaga Kebersihan Genetalia Eksterna Dengan Kejadian Keputihan pada Siswa SMA N 4 Semarang

14. Asyirna. 2013. Hubungan tingkat pengetahuan dan sikap remaja putri
Volume 5 Nomor 1, April 2020 p-

tentang personal hygine dengan kejadian keputihan pada remaja putri kelas XI DI SMA kota bukit tinggi 